\title{
Morphophysiology, Phenotypic and Molecular Diversity of Auxin- induced Passiflora mucronata Lam. (Passifloraceae)
}

\author{
JULIANY M. FRANÇA ${ }^{1}$, LUCIMARA R. VENIAL ${ }^{2}$, ELOÁ B. COSTA ${ }^{2}$, EDILSON R. \\ SCHMILDT ${ }^{1}$, OMAR SCHMILDT ${ }^{1}$, PAULA M. BERNARDES ${ }^{2}$, SANDRO D. TATAGIBA ${ }^{3}$, \\ JOSÉ C. LOPES ${ }^{2}$, MARCIA F.S. FERREIRA ${ }^{4}$ and RODRIGO S. ALEXANDRE ${ }^{4}$ \\ ${ }^{1}$ Departamento de Ciências Agrárias e Biológicas, Centro Universitário Norte do Espírito Santo, Universidade \\ Federal do Espírito Santo, Rodovia BR 101 Norte, Km 60, 29932-540 São Mateus, ES, Brazil \\ ${ }^{2}$ Departamento de Agronomia, Centro de Ciências Agrárias e Engenharias, Universidade Federal do \\ Espírito Santo, Alto Universitário, s/n, Bairro Guararema, 29500-000 Alegre, ES, Brazil \\ ${ }^{3}$ Instituto Federal de Educação, Ciência e Tecnologia do Pará, Campus Itaituba/IFPA, \\ Estrada Jacarezinho, s/n, Maria Magdalena, 68183-300 Itaituba, PA, Brazil \\ ${ }^{4}$ Universidade Federal do Espírito Santo, Centro de Ciências Agrárias e Engenharias, Avenida \\ Governador Lindemberg, 316, Centro, 29550-000 Jerônimo Monteiro, ES, Brazil
}

Manuscript received on December 23, 2016; accepted for publication on December 20, 2017

\begin{abstract}
Genetic diversity allows identification of potential intraspecific genotypes in the genus Passiflora. The objective of this study was to examine the morphological and genetic diversity of auxin-induced Passiflora mucronata. The experiments were arranged in a complete randomized block design, with a $9 \times 2$ factorial arrangement (nine genotypes x presence and absence of auxin, indole-3-butyric acid (IBA)), with four replicates of 16 cuttings. The rooting and vegetative growth responses were variable. Genotype 5 was more responsive in the absence of IBA and genotypes 3, 8 and 9 were more responsive in the presence of IBA. Auxin increased rooting rate and percentage, reducing the average time of root protrusion in eight days. IBA also contributed to increase photosynthesis and dry root and shoot mass in 55.55 and $44.44 \%$ of the genotypes, respectively. The highest relative contribution to phenotypic diversity in the absence of auxin was rate $(38.75 \%)$ and percentage $(20.27 \%)$ of rooting, whereas in the presence of auxin was stomatal conductance $(23.19 \%)$ and root dry mass $(20.91 \%)$. Similarity was found for phenotypic and molecular divergence in the presence of IBA, in which genotypes 1 and 6; genotypes 5, 8 and 9; and genotype 3 were clustered in distinct groups.
\end{abstract}

Key words: indol-3-butyric acid, rooting, genotypes, restinga passion fruit, molecular markers ISSR, propagation.

\section{INTRODUCTION}

The passion fruit species Passiflora mucronata

Correspondence to: Rodrigo Sobreira Alexandre

E-mail: rodrigosobreiraalexandre@gmail.com is self-incompatible (Meletti et al. 2011) and, predominantly allogamous, hence, there is intraspecific genetic variability to be explored. Molecular markers such as Inter Simple Sequence Repeats (ISSR) can be used to characterize genetic 
variability, as phenotypic markers, which are characterized by simultaneous analysis of multiple traits, and have the advantage of be represented graphically.

The dissimilarity measures most commonly used to assess genetic divergence among genotypes (GEN) of plant species are the Mean Euclidean Distance and Mahalanobis distance $\left(\mathrm{D}^{2}{ }_{\mathrm{ii}}\right)$. The $\mathrm{D}^{2}$ ii , is preferable because it is estimated when the matrix of variances and residual covariances is available. These matrices can only be estimated when genotypes are evaluated in experimental trials with replicates (Cruz et al. 2012). On the other hand, the basic purpose of canonical variables is to provide a structural simplification of the data so that genetic diversity, which is influenced in principle by the $p$-dimensional set ( $p=$ number of characters considered in the study), can be evaluated by a bi or three-dimensional complex of easy geometric interpretation (Cruz et al. 2012).

Identification of distinct groups of $P$. mucronata genotypes and evaluation of their morphophysiological behavior are important for early selection of promising rootstocks for commercial species. The commercial cultivars of Passiflora edulis have low levels of resistance to a number of diseases caused mainly by fungi, bacteria and viruses, which have led to a shortened plant life cycle in the field. (Junqueira et al. 2003, Pinto et al. 2008). Nevertheless, some resistant species to the fungus Fusarium solani (Preisigke et al. 2015) have been found among the native passifloraceae, including $P$. quadrangulares L., $P$. nitida Kunth and $P$. foetida L. These resistant species also have genetic compatibility with Passiflora edulis (Junqueira et al. 2005), which will develop normally even in soils contaminated by pathogens. Resistance to Fusarium solani was also detected in two hybrids derived from the interspecific cross between $P$. edulis (susceptible) and $P$. mucronata (resistant), which can be as rootstock for $P$. edulis (Freitas et al. 2015).
Rootstocks can be produced by seeds or vegetative propagation using cuttings. Cuttings have the advantages resistance of fixation to soil diseases, in which the native "Passifloraceae" can be used as rootstocks for commercial passion fruit. The rhizogenic capacity is influenced, among other factors, by growth regulators, mainly auxins, for example indole-3-butyric acid (IBA). P. mucronata cuttings are more responsive to rhizogenesis when treated with IBA (Alexandre et al. 2014), but others need not the use of this regulator (Alexandre et al. 2016), therefore, there is a variation between genotypes regarding the responsiveness to this growth regulator and more studies are necessary. It is important to determine an ideal concentration of IBA for the species $P$. mucronata, in order to promote a higher rhizogenic speed, besides a more developed root system increase nutritional absorption favoring in this sense, the rapid development.

The objective of this study was to analyze the morphological behavior and the molecular and phenotypic diversity of $P$. mucronata treated or not with indole-3-butyric acid (IBA).

\section{MATERIALS AND METHODS}

\section{MATERIAL VEGETAL}

The experiments were carried out in the experimental area of the Center of Agricultural Sciences and Engineering (CCAE) of the Federal University of Espírito Santo (UFES), in Alegre, ES, Brazil, geographical coordinates $20^{\circ} 47^{\prime} 43$ 'S and $41^{\circ} 30$ '33"W, $210 \mathrm{~m}$ altitude. The genotypes of Passiflora mucronata were collected at Cedro Farm located in the municipality of Jaguaré, in northern Espírito Santo.

The study consisted of two experiments: the first experiment analyzed the vegetative propagation, growth and gas exchange of genotypes (GEN) 1, 2, $3,4,5,6,7,8$ and 9 treated and untreated with IBA (indol-3-butyric acid), and the second experiment 
analyzed the phenotypic and molecular diversity of genotypes $1,2,3,4,5,6,7,8$ and 9 of $P$. mucronata genotypes

EXPERIMENT I: ROOTING PERCENTAGE, ROOT SPEED GROWTH AND GAS EXCHANGE IN AUXIN TREATED AND UNTREATED GENOTYPES OF $P$. mucronata.

\section{Percentage and rooting speed}

The cuttings were planted in $50 \mathrm{~L}$ pots and trained in the espalier system to increase the number of plants and branches of the same genotype and be used in the adventitious rooting experiment later. After 12 months, cuttings of adult plants of all genotypes were taken with $12 \mathrm{~cm}$ length and 2-3 mm diameter, without leaves, with two nodes, bevel cuts at the base, and treated or not with IBA $\left(1000 \mathrm{mg} \mathrm{L}^{-1}\right)$ in talc. The cuttings were grown in styrofoam trays with $40 \mathrm{~cm}^{3}$ cells using Bioplant ${ }^{\circledR}$ substrate and kept in a greenhouse under intermittent misting.

At 58 days after the experiment started, the following characteristics were analyzed: rooting (R\%); root protrusion rate (RRP), which was recorded daily by counting the protrusion of the first root at the base of each cutting and the mean time of root protrusion (MRPT, in days).

\section{Gas exchange and dry mass accumulation}

Seedlings of nine P. mucronata genotypes from the previous experiment were grown on vertical trellises, full sun, in the experimental area of CCAE/UFES, in $18 \mathrm{~L}$ pots filled with commercial substrate $\left(\right.$ Bioplant $\left.^{\circledR}\right)$. The substrate had the following chemical characteristics: total organic matter (8.5 dag $\left.\mathrm{kg}^{-1}\right)$; $\mathrm{pH}$ in $\mathrm{H}_{2} \mathrm{O}$ : 5.2; $\mathrm{P}$ Mellich (198 $\left.\mathrm{mg} \mathrm{dm}^{-3}\right) ; \mathrm{Na}^{+}\left(510 \mathrm{mg} \mathrm{dm}{ }^{-3}\right)$; exchangeable $\mathrm{K}^{+}$(990 $\left.\mathrm{mg} \mathrm{dm}^{-3}\right)$; exchangeable $\mathrm{Mg}^{2+}$ (3.2 cmol); exchangeable $\mathrm{Ca}^{2+}(78 \mathrm{cmol})$; exchangeable $\mathrm{Ca}^{2+}+$ $\mathrm{Mg}^{2+}\left(11 \mathrm{mmol}_{\mathrm{c}} \mathrm{dm}^{-3}\right) ; \mathrm{Al}^{3+}(0.4 \mathrm{cmol}) ; \mathrm{H}^{+}+\mathrm{Al}^{3+}$ $(4.7 \mathrm{cmol})$; Zn $\left(15.2 \mathrm{mg} \mathrm{dm}^{-3}\right)$; Fe $\left(206 \mathrm{mg} \mathrm{dm}^{-3}\right)$;
Mn (45 mg dm $\left.{ }^{-3}\right) ; \mathrm{Cu}\left(2.4 \mathrm{mg} \mathrm{dm}^{-3}\right) ; \mathrm{B}$ (1.22 mg $\left.\mathrm{dm}^{-3}\right)$; CEC (t) $(13.9 \mathrm{cmol})$; base saturation (74.2 $\%$; and physical characteristics: dry or wet density $\left(303.59 \mathrm{~kg} \mathrm{~m}^{-3}\right)$; total porosity $(64.09 \%)$; particle size (mm): $>4.75(0.07 \%) ; 2$ to $4.75(34.56 \%) ; 1$ to 2 (43.36\%); 0.5 to 1 (18.78\%); 0.25 to 0.5 (2.31\%) and $<0.25(0.92 \%)$ (MAPA 2007). Supplemental fertilizations were carried out with macro and micronutrients (NPK: 10-10-10) and FTE (S: 3.9\%; B: $1.8 \%$; Mn: $2 \%$ and $\mathrm{Zn}$ : $9 \%$ ). Manual irrigation was carried out when necessary, providing $3 \mathrm{~L}$ of water per pot. Gas exchange analyses were performed four months after planting.

The photosynthetic parameters were measured on mature fully expanded leaves free of insect attack and abiotic lesions in the nine genotypes in study. Net $\mathrm{CO}_{2}$ assimilation rate $\left(A, \mu \mathrm{mol} \mathrm{m} \mathrm{m}^{-2} \mathrm{~s}^{-1}\right)$; stomatal conductance to water vapor ( $\mathrm{gs}$, mol of $\left.\mathrm{H}_{2} \mathrm{O} \mathrm{m}^{-2} \mathrm{~s}^{-1}\right)$; transpiration rate $\left(E\right.$, mmol of $\mathrm{H}_{2} \mathrm{O}$ $\left.\mathrm{m}^{-2} \mathrm{~s}^{-1}\right)$, internal $\mathrm{CO}_{2}$ concentration $\left(\mathrm{Ci}, \mu \mathrm{mol} \mathrm{m} \mathrm{m}^{-2}\right.$ $\mathrm{s}^{-1}$ ), under exposure to irradiance of $1000 \mu \mathrm{mol}$ of photons $\mathrm{m}^{-2} \mathrm{~s}^{-1}$ and ambient $\mathrm{CO}_{2}$ concentration $\left(\mathrm{C}_{a}\right)$ of $400 \pm 8 \mu \mathrm{mol} \mathrm{CO}_{2} \mathrm{~mol}^{-1}$ were measured between 9:00 a.m. and 10:30 a.m., with maximum $A$, using a portable infrared gas analyser (LI-6400; LI-COR Inc., Nebraska, USA).

Following gas exchange measurements, shoots and roots were separated, placed in paper bags, dried in a convection oven at $75{ }^{\circ} \mathrm{C}$ for 72 $\mathrm{h}$ then weighed in analytical balance $(0.0001 \mathrm{~g})$ to determine root dry mass (RDM) and shoot dry mass (SDM).

\section{Experimental design}

The experiment was arranged in a $9 \times 2$ factorial randomized block design, (genotypes $1 ; 2 ; 3$; $4 ; 5 ; 6 ; 7 ; 8$ and 9 x seedlings from treated or untreated cuttings with IBA (1000 $\left.\mathrm{mg} \mathrm{kg}^{-1}\right)$, with four replications of 16 seedlings per plot. Data were examined by analysis of variance, means of the different genotypes were compared by the 
Scott-Knott's test and presence and absence of auxin by the Tukey's test and Pearson's phenotypic correlation.

\section{EXPERIMENT II: PHENOTYPIC AND MOLECULAR} DIVERSITY OF P. mucronata GENOTYPES

The phenotypic diversity of nine $P$. mucronata genotypes treated or untreated with auxin was analyzed through morphological characteristics, including rooting $(\mathrm{R}, \%)$, rate of root protrusion (RRP), mean root protrusion time (MRPT, days), dry mass of roots (RDM, grams) and shoots (SDM, grams), and physiological characteristics, including net $\mathrm{CO}_{2}$ assimilation rate $\left(A, \mu \mathrm{mol} \mathrm{m}{ }^{-2}\right.$ $\mathrm{s}^{-1}$ ), stomatal conductance to water vapor ( $\mathrm{gs}, \mathrm{mol}$ of $\left.\mathrm{H}_{2} \mathrm{O} \mathrm{m}^{-2} \mathrm{~s}^{-1}\right)$, transpiration rate $(E, \mathrm{mmol}$ of $\left.\mathrm{H}_{2} \mathrm{O} \mathrm{m}^{-2} \mathrm{~s}^{-1}\right)$, and internal $\mathrm{CO}_{2}$ concentration $(\mathrm{Ci}$, $\left.\mu \mathrm{mol} \mathrm{m} \mathrm{m}^{-2} \mathrm{~s}^{-1}\right)$, using a scatter plot of the first two canonical variables, for genotypes IBA-treated and IBA-untreated separately, with the generalized Mahalanobis distance. The scatterplot shows the genotypes separated into clusters by the Tocher's method, using the Genes program (Cruz 2016).

For analysis of molecular diversity, the genomic DNA of the nine P. mucronata genotypes were extracted from young leaves of each genotypes according to protocol of Doyle and Doyle (1990), with the following changes: addition of $1 \%$ (w/v) polyvinylpyrrolidone to extraction buffer; two washings with chloroform-isoamyl alcohol (24:1); and for precipitation were used a third of ammonium acetate $(7.5 \mathrm{M})$ and one volume of cold isopropanol. The samples were resuspended in $40 \mu \mathrm{L}$ of TE buffer ( $10 \mathrm{mM}$ Tris- $\mathrm{HCl}, \mathrm{pH} 8.0$, and $1 \mathrm{mM}$ EDTA) containing $40 \mu \mathrm{g} \mathrm{mL}{ }^{-1}$ RNase A. The genomic DNA integrity was analyzed on $0.8 \%$ agarose gel stained with ethidium bromide and DNA concentration and purity was determined by spectrophotometry.

For the analyzes with ISSR (Inter Simple Sequence Repeats) markers, previously 40 markers were amplified in samples of $P$. mucronata, of which seven were chosen for analysis in all samples analyzed. The markers were chosen by the band pattern to be of clear identification and by their reproducibility. DNA amplifications were carried out with the ISSR primers $807,808,809$, 810, 811 and 834, from UBC (University of British Columbia). Each Polymerase Chain Reaction (PCR) reaction contained $30 \mathrm{ng}$ of DNA, $0.5 \mu \mathrm{M}$ primer and $1 \mathrm{U}$ of Taq DNA polymerase in a final volume of $13 \mu \mathrm{L}$.

The samples were denatured at $94{ }^{\circ} \mathrm{C}$ for $5 \mathrm{~min}$ followed by 35 cycles of $94{ }^{\circ} \mathrm{C}$ for $1 \mathrm{~min}, 50{ }^{\circ} \mathrm{C}$ for $1 \mathrm{~min}$ and $72{ }^{\circ} \mathrm{C}$ for $1 \mathrm{~min}$ and final extension at 72 ${ }^{\circ} \mathrm{C}$ for $10 \mathrm{~min}$. PCR products were visualized on $1.5 \%$ agarose gels stained with ethidium bromide $(1 \%-10 \mathrm{~mL})$ and photographed under UV light. The fragments were compared with a $100 \mathrm{bp}$ DNA ladder (Thermo Scientific ${ }^{\circledR}$ ).

Distances among the nine $P$. mucronata genotypes were obtained by the simple matching dissimilarity coefficient (SMC) based on the coded molecular markers and clustering was performed by UPGMA (Unweighted Pair-Group Method Using Arithmetic Averages). The analyses were performed using the statistical software Genes (Cruz 2016).

\section{RESULTS AND DISCUSSION}

EXPERIMENT I: ROOTING, ROOT VIGOR, GROWTH AND GAS EXCHANGE IN AUXIN TREATED AND UNTREATED CLONAL GENOTYPES OF P. mucronata

Rooting of leafless cuttings was greater with the IBA $\left(1000 \mathrm{mg} \mathrm{kg}^{-1}\right)$ treatment, varying from $32.81 \%$ (GEN 1) to $93.75 \%$ (GEN 5). With the auxin, the highest rooting percentages were recorded for genotypes 3 (92.19\%), 5 (93.75\%), 8 (87.50\%), and $9(84.38 \%)$ (Table I). IBA positively regulates the transport of amino acids and nucleotides and negatively the expression of genes associated with secondary metabolism, including the synthesis of 
flavonoids and lignin biosynthesis during the initial phase of adventitious rooting (Li et al. 2016). These genetic differences in rooting ability may, for example, be due to a delay in the early activation of cell divisions as observed in Dianthus caryophyllus (Villacorta-Martín et al. 2015). However, the authors observed that the lower rooting capacity of cv. R8 2003 in relation to cv. MFR 2101-02 was directly associated with the low auxin x cytokinin ratio in this cultivar. Genotypes of Eucalyptus globulus showed differences in cytokinins levels, varying in their rooting capacity. Moreover, a higher level of cytokinin in the shoot was correlated with the rooting percentage. Auxins and cytokinins play a key role in adventitious root formation of $E$. globulus and a complex interaction between auxin and cytokinin levels in their metabolism may result in root formation. However, indole-3-acetic acid (IAA) levels were the same among genotypes of difficult and easy rooting, whereas levels of IAAsp (indole-3-acetyl aspartic acid) were higher in the genotype of difficult rooting, suggesting that the IAA metabolism may play an important role in the adventitious root formation of this species (Negishi et al. 2014).

However, even with the auxin, GENs 1, 2, 4, 6, and 7 showed rooting below 55\% (Table I). Alexandre et al. (2014) found rooting of $86 \%$ for one-node cuttings with one half-leaf of $P$. mucronata treated with IBA (1000 mg kg-1) and also observed that the root quality was higher when crystalline IBA was applied in a mixture with talc. Some GENs within the same species were found to be more responsive to root induction than others, and this may be related to a number of endogenous factors inherent to each genetic material. Mouri et al. (2011) treated Pinus thunbergii cuttings with ethrel $(69.2 \mu \mathrm{M}$ ethefon) for $24 \mathrm{~h}$ and reported a greater rooting capacity. There are, therefore, several inducers of adventitious rooting, including hormones such as ethylene.

TABLE I

Rooting (\%), rate of root protrusion (RRP), and mean root protrusion time (MRPT) of cuttings of nine P. mucronata genotypes treated and untreated with indole-3-butyric acid (IBA).

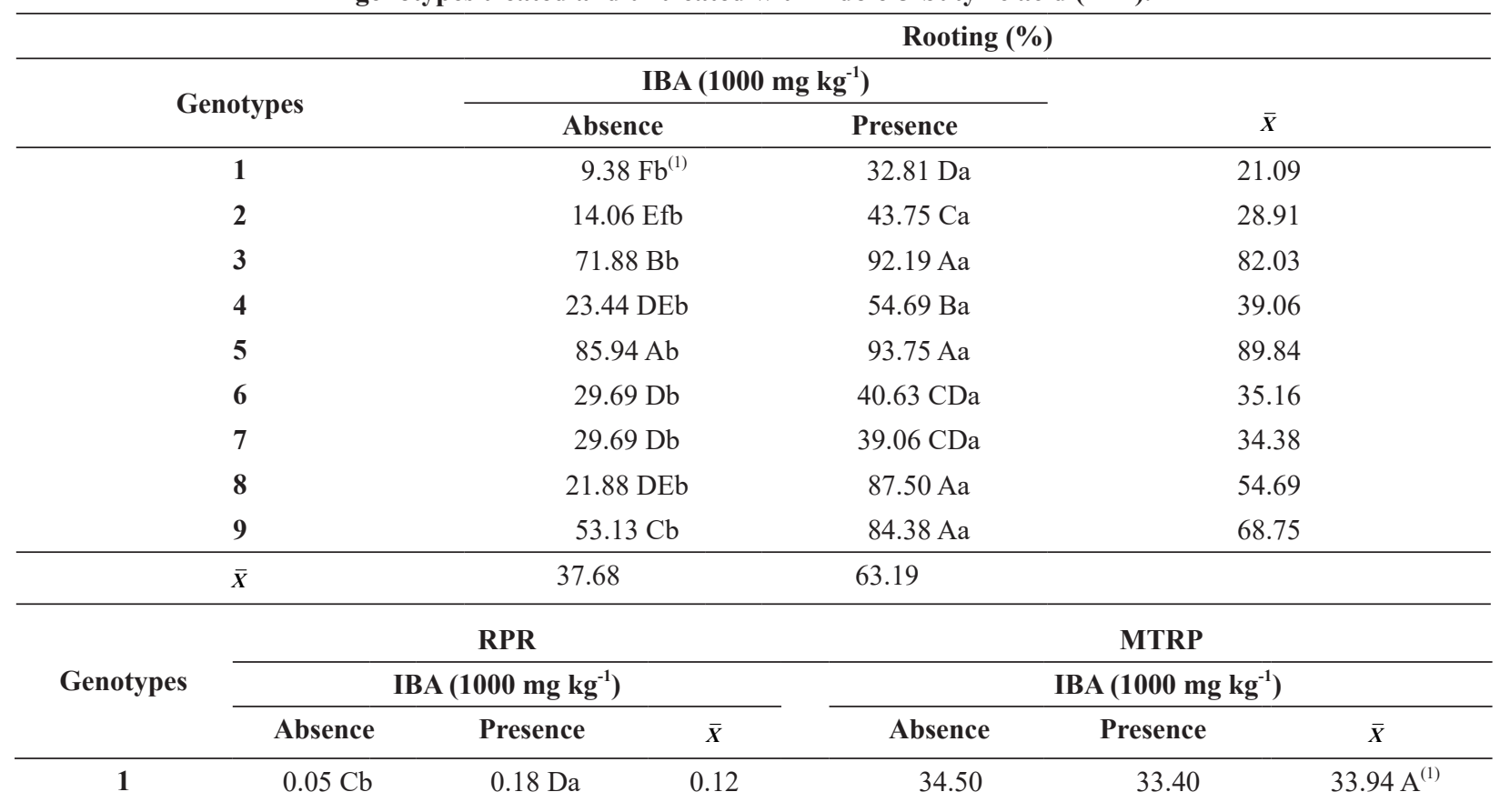


TABLE I (continuation)

\begin{tabular}{|c|c|c|c|c|c|c|}
\hline \multirow{3}{*}{ Genotypes } & \multicolumn{3}{|c|}{ RPR } & \multicolumn{3}{|c|}{ MTRP } \\
\hline & \multicolumn{3}{|c|}{ IBA $\left(1000 \mathrm{mg} \mathrm{kg}^{-1}\right)$} & \multicolumn{3}{|c|}{ IBA (1000 $\left.\mathrm{mg} \mathrm{kg}^{-1}\right)$} \\
\hline & Absence & Presence & $\bar{x}$ & Absence & Presence & $\overline{\bar{X}}$ \\
\hline 2 & $0.06 \mathrm{Cb}$ & $0.29 \mathrm{Cda}$ & 0.17 & 34.65 & 29.00 & $31.82 \mathrm{AB}$ \\
\hline 3 & $0.50 \mathrm{Ab}$ & $0.97 \mathrm{Aa}$ & 0.73 & 27.90 & 18.70 & $23.30 \mathrm{~B}$ \\
\hline 4 & $0.10 \mathrm{Cb}$ & $0.33 \mathrm{Ca}$ & 0.22 & 41.54 & 29.27 & $35.41 \mathrm{~A}$ \\
\hline 5 & $0.54 \mathrm{Ab}$ & $0.65 \mathrm{Ba}$ & 0.59 & 29.31 & 25.46 & $27.39 \mathrm{AB}$ \\
\hline 6 & $0.14 \mathrm{Cb}$ & $0.33 \mathrm{Ca}$ & 0.24 & 37.73 & 24.32 & $31.02 \mathrm{AB}$ \\
\hline 7 & $0.15 \mathrm{Cb}$ & $0.30 \mathrm{CDa}$ & 0.22 & 36.20 & 26.26 & $31.23 \mathrm{AB}$ \\
\hline 8 & $0.12 \mathrm{Cb}$ & $0.64 \mathrm{Ba}$ & 0.38 & 31.63 & 26.55 & $29.09 \mathrm{AB}$ \\
\hline 9 & $0.27 \mathrm{Bb}$ & $0.57 \mathrm{Ba}$ & 0.42 & 39.14 & 28.87 & $34.01 \mathrm{~A}$ \\
\hline $\bar{X}$ & 0.21 & 0.47 & & $34.73 \mathrm{a}$ & $26.87 \mathrm{~b}$ & \\
\hline
\end{tabular}

(1) Means followed by the same capital letter in the columns and small letter in the rows are not significantly different by the ScottKnott's test and Tukey's test at 5\% probability level, respectively.

A number of intrinsic and extrinsic factors, including $\mathrm{Ca}^{2+}$, sugars, auxins, polyamines, ethylene, nitric oxide, hydrogen peroxide, carbon monoxide, cGMP, MAPKs, and peroxidases control the formation of adventitious roots. They function as receptors, receiving and emitting signals, and auxin is then signalized in parallel with adventitial root formation (Li et al. 2009). These substances, which account for root formation, are carried to the rooting zone of the cutting and there they remain accumulated and promote root initiation (Hartmann et al. 2011).

Softwood cuttings of $P$. setacea, $P$. coccinea, $P$. amethystina, $P$. edulis, $P$. edulis $\times$ P. setacea and $P$. coccinea $\mathrm{x}$ P. setacea showed increased rooting, sprouting, root dry mass, and total dry mass with increasing IBA concentration up to $1000 \mathrm{mg} \mathrm{L}^{-1}$ (Faria Vaz et al. 2009). P. nitida cuttings treated with IBA showed greater rooting at the concentrations of $1000(88.75 \%), 3000(95 \%)$ and 5000 (98.75\%), which differed significantly from the control $(0 \mathrm{mg}$ $\mathrm{L}^{-1}$ ), reaching 62.5\% (Sabião et al. 2011).

Clove (Dianthus caryophyllus) cultivars 2003 R8 and 2101-02 MFR presented in the beginning of root primordia formation some cambium cells, between the phloem and xylem, with periclinal divisions in response to the endogenous auxin signal, showing differences in rooting capacity among cultivars due to a delay in the early activation of cell divisions (Villacorta-Martín et al. 2015). However, the authors observed that the lower rooting ability of cv. 2003 R8 was directly associated with the low auxin $\mathrm{x}$ cytokinin ratio in this cultivar.

Genotypes of Eucalyptus globulus showed differences in cytokinins levels among genotypes, varying in their rooting capacity. Moreover, a higher level of cytokinin in the shoot was correlated with the rooting percentage. Auxins and cytokinins play a key role in adventitious root formation of $E$. globulus and a complex interaction between auxin and cytokinin levels in their metabolism may result in root formation. However, indole-3-acetic acid (IAA) levels were the same among genotypes of difficult and easy rooting, whereas levels of IAAsp (indole-3-acetyl aspartic acid) were higher in the genotype of difficult rooting, suggesting that the IAA metabolism may play an important role in the adventitious root formation of this species (Negishi et al. 2014).

High rooting capacity was found for GENs 5 $(85.94 \%)$ and $3(71.88 \%)$ in the absence of auxin, 
while GENs 1, 2, 4, 6, 7 and 8, showed rooting below 30\% (Table I). Alexandre et al. (2016) reported $(85.9 \%)$ rooting for two node cuttings (without leaves) of $P$. mucronata not treated with IBA. The higher endogenous contents of auxins in the cuttings may account for this response, without the need of leaves, which can help in the reduction of water loss. In Petunia hybrid, about $40 \%$ of IAA is in the leaves, $12 \%$ in the older leaves, and about $60 \%$ in stem tissue, and $11 \%$ in the root formation zone (Ahkami et al. 2013). Alexandre et al. (2014) found rooting in $65.47 \%$ of $P$. mucronata cuttings without IBA treatment, suggesting a substantial variation among the genotypes of this species regarding rooting capacity. The adventitious rooting in cuttings of 15 P. alata genotypes was not favored by application of IBA (2000 $\mathrm{mg} \mathrm{kg}^{-1}$ ) (Alexandre et al. 2013). The same was reported by Sousa et al. (2014) for P. alata cuttings (with and with no leaves) treated with $0 ; 1000 ; 2000$ and $4000 \mathrm{mg}$ $\mathrm{L}^{-1}$ of IBA. In Piper nigrum L., IBA untreated and treated cuttings showed 10.74 and $64.5 \%$ (6000 mg $\mathrm{kg}^{-1}$ ), 39.96 and $98.7 \%$ (3351 $\mathrm{mg} \mathrm{kg}^{-1}$ ), and 44.45 and $91.8 \%$ (3866 $\left.\mathrm{mg} \mathrm{kg}^{-1}\right)$ of nodal rooting in cvs. Bragantina, Iaçará and Guajarina, respectively (Secundino et al. 2014). It was found, therefore, increase in rooting capacity of this Piperaceae cultivars with auxin, and that each genetic material may require different auxin concentrations.

IBA positively influenced the root vigor of cuttings of the P. mucronata genotypes. Gen 3 was the most vigorous in the absence and presence of auxin (Table I), which may be related to the morphology of the mother plant, such as larger diameter branches, well-developed leaves and appearance of nutritional vigor (data not shown), as weii as physiological traits, such as less lignified cuttings and nutritional status, hormonal balance, auxin/cytokinin ratio and other co-factors suitable for rooting.

MRPT of IBA-treated cuttings was 27 days and MRPT of untreated cuttings was 35 days, a difference of 8 days of advance in rooting with auxin. GEN 3 had the lowest MRPT (23.3 days) and GENs 1 (33.94 days), 4 (35.41 days) and 9 (34.01 days) the highest MRPT (Table I). This higher rate of root emission in these genotypes of P. mucronata may be related to a greater efficiency in the metabolism of sugars and enzymes with the use of auxin, for example, of the species Dalbergia sisso Roxb. in which the IBA treated stakes maintained higher levels of protein and peroxidase activity (PER) in the rooting zone. In this species, total soluble sugars and starch decreased during root growth. Protein content and PER activity began to increase in the initial growth phase and reached the highest level on day 21 after planting, followed by a decline on day 35 after planting. In general, these results suggest that auxin treatment may have activated carbohydrate metabolism for energy release, whereas protein and PER activity was required for cell division and differentiation during initiation and development of root primordia in the rooting of cuttings (Husen 2008). The reduction in time of root protrusion is important for the early establishment of the root system, which will reduce the seedling production time and quickly ensure its survival. This reduction in time reflects, for example, on a shorter production time for rootstocks, in which the rapid emission of the root system results in tissue rehydration and nutrient uptake for growth in height and collar diameter, however, the longer time required for rooting can expose the stake to sub-optimal environmental conditions (Aiello and Graves 1998). Moreover, root collar diameter is a morphological indicator for attaining the proper time for grafting on a rootstock (hypobiote). According to Andrade Júnior et al. (2013), the index resulting from the relationship between the height of the seedling and the diameter of the stem expresses the growth equilibrium, also called the robustness quotient, which is considered one of the highest indexes since it provides information about how fine the seedlings are. 
The hybrid Corymbia torelliana x Corymbia citriodora shows higher rooting and higher vigor in apical cuttings because they are less lignified and sclerenchymatic than the basal ones (Wendling et al. 2015). In this case, the epigenetic variation originated from the topophysis effect (effect of origin), that is, effect of position in the branch, is more evident as the physiological age advances. In Passiflora actinia there was greater rooting in basal cuttings with leaves $(75 \%)$ than in middle cuttings with leaves (41.75\%), while the apical cuttings died (Albuquerque Junior et al. 2013).

Exogenous auxins stimulate initiation and inhibit the later stages of adventitious root development (Klerk et al. 1995). The induction phase in adventitious root formation (AR) is positively regulated by auxin, polyamines, cytokinins and ethylene, in addition to the double role of cytokinins and ethylene that negatively regulates abscisic acid (ABA) induction. Nitric oxide (NO) stimulates induction and initiation of AR (Porfírio et al. 2016). However, strigolactones generally reduce the ability to induce roots (Verstraeten et al. 2014), suppressing auxin action. On the other hand, strigolactones are upregulated along with gibberellins (GA) at root initiation, and while ethylene and GA stimulate AR expression, ABA represses it (Porfírio et al. 2016). According to Verstraeten et al. (2014), the participation of these many regulators suggests the existence of rigid control and fine-tuning of adventitious root initiation and emergence. Souza et al. (2015) evaluated the carbohydrate content in vine cuttings of rootstock cv. IAC 572 and found that cuttings treated with organic substrate in association with IBA had reserve substances significantly increased. Fachinello et al. (2005) argued that abundant carbohydrate reserves provide higher percentages of rooting and survival of cuttings.

The clonal genotypes of $P$. mucronata had similar physiological behavior with the following means: $10.69 \mu \mathrm{mol} \mathrm{CO} \mathrm{m}^{-2} \mathrm{~s}^{-1}(A), 0.35 \mathrm{~mol} \mathrm{~m}^{-2}$
$\mathrm{s}^{-1}\left(g_{S}\right), 305.75 \mu \mathrm{mol} \mathrm{mol}{ }^{-1}\left(C_{i}\right)$, and $10.51 \mathrm{mmol}$ $\mathrm{H}_{2} \mathrm{O} \mathrm{m}^{-2} \mathrm{~s}^{-1}(E)$ (Table II). Vasconcellos et al. (2005) reported for $P$. giberti, $P$. cincinnata and $P$. edulis $\mathrm{f}$. flavicarpa $A$ means of $15 ; 13.5$ and $9.5 \mu \mathrm{mol} \mathrm{CO}_{2}$ $\mathrm{m}^{-2} \mathrm{~s}^{-1}$, respectively. The authors found reduction of the net photosynthesis rate of approximately 85 to $95 \%$ in leaves on the inside of the canopy, indicating that the auto-shading interferes effectively in the availability of photosynthetically active radiation (RFA). In the same way, the stomatal conductance $(g s)$ and transpiration (E) are affected by leaf position, also leading to a lower value of $A$ by the non-opening of the stomata.

Genotypes from cuttings treated with IBA $\left(1000 \mathrm{mg} \mathrm{L}^{-1}\right)$ had higher $A$ means $(11.54 \mu \mathrm{mol} \mathrm{CO}$ $\left.\mathrm{m}^{-2} \mathrm{~s}^{-1}\right)$ than the untreated ones $\left(9.84 \mu \mathrm{mol} \mathrm{CO} \mathrm{Cm}^{-2}\right.$ $\mathrm{s}^{-1}$ ) (Table II). It is mainly because the characteristic of the growth regulator, since auxins stimulate root vigor, favoring the early adaptive capacity of plants. The root vigor allows better absorption of water and nutrients, favoring allometric growth and leading to a greater accumulation of shoot and root dry mass. The other characteristics $g_{S}, E$ and $C i$, showed no significant differences (Table II).

It is interesting that the vegetative propagation of $P$. cincinnata Mast. by cuttings can preserve the water status of plant tissues, however, there is a reduction in both vegetative development and $A\left(10 \mu \mathrm{mol} \mathrm{CO} \mathrm{m}^{-2} \mathrm{~s}^{-1}\right)$, when compared with seed propagation, which had higher $g s(0.3 \mathrm{~mol}$ $\left.\mathrm{m}^{-2} \mathrm{~s}^{-1}\right)$ and $A\left(13 \mu \mathrm{mol} \mathrm{CO} \mathrm{CO}^{-2} \mathrm{~s}^{-1}\right)$ and reduced leaf turgescence at the beginning of vegetative growth (90 DAT) (Santos et al. 2016). Propagation by cuttings or grafting reduces the juvenile period of several fruit tree species (Isutsa 2006); therefore, differences in vegetative characteristics were related to the shortening of juvenile period in cuttings, resulting in clones having lower vegetative growth than seedlings. Gama et al. (2013) evaluated seedlings of five $P$. edulis cultivars and found $A$ values ranging from 10.86 to $18.07 \mu \mathrm{mol} \mathrm{m} \mathrm{m}^{-2} \mathrm{~s}^{-1}$, above the mean obtained in 
TABLE II

Net photosynthesis rate $(A)$, stomatal conductance $(g s)$, internal carbon $(C i)$, and leaf transpiration rate $(E)$ of nine $P$. mucronata genotypes treated and untreated with indole-3-butyric acid (IBA).

\begin{tabular}{|c|c|c|c|c|}
\hline Genotypes & $\begin{array}{c}A \\
\left(\mu \mathrm{mol} \mathrm{CO} \mathrm{Cm}^{-2} \mathrm{~s}^{-1}\right)\end{array}$ & $\begin{array}{c}g_{S} \\
\left(\mathrm{~mol} \mathrm{~m}^{-2} \mathrm{~s}^{-1}\right)\end{array}$ & $\begin{array}{c}C i \\
\left(\mu \mathrm{mol} \mathrm{mol}{ }^{-1}\right)\end{array}$ & $\begin{array}{c}E \\
\left(\mathrm{mmol} \mathrm{H}_{2} \mathrm{O} \mathrm{m}^{-2} \mathrm{~s}^{-1}\right)\end{array}$ \\
\hline 1 & $10.15 \mathrm{a}^{(1)}$ & $0.33 \mathrm{a}$ & $309.50 \mathrm{a}$ & $10.06 \mathrm{a}$ \\
\hline 2 & $10.85 \mathrm{a}$ & $0.32 \mathrm{a}$ & $301.33 \mathrm{a}$ & $9.15 \mathrm{a}$ \\
\hline 3 & $9.60 \mathrm{a}$ & $0.37 \mathrm{a}$ & $312.83 \mathrm{a}$ & $10.70 \mathrm{a}$ \\
\hline 4 & $12.65 \mathrm{a}$ & $0.42 \mathrm{a}$ & $306.33 \mathrm{a}$ & $11.71 \mathrm{a}$ \\
\hline 5 & $11.03 \mathrm{a}$ & $0.38 \mathrm{a}$ & $295.33 \mathrm{a}$ & $10.65 \mathrm{a}$ \\
\hline 6 & $10.25 \mathrm{a}$ & $0.33 \mathrm{a}$ & $308.50 \mathrm{a}$ & $10.71 \mathrm{a}$ \\
\hline 7 & $10.28 \mathrm{a}$ & $0.32 \mathrm{a}$ & $305.50 \mathrm{a}$ & $10.05 \mathrm{a}$ \\
\hline 8 & $9.95 \mathrm{a}$ & $0.29 \mathrm{a}$ & $303.00 \mathrm{a}$ & $9.73 \mathrm{a}$ \\
\hline 9 & $11.48 \mathrm{a}$ & $0.41 \mathrm{a}$ & $309.50 \mathrm{a}$ & $11.85 \mathrm{a}$ \\
\hline $\bar{X}$ & 10.69 & 0.35 & 305.75 & 10.51 \\
\hline $\begin{array}{c}\text { IBA } \\
\left(1000 \mathrm{mg} \mathrm{kg}^{-1}\right) \\
\end{array}$ & $\begin{array}{c}A \\
\left(\mu \mathrm{mol} \mathrm{CO} \mathrm{Cm}_{2}^{-2} \mathrm{~s}^{-1}\right) \\
\end{array}$ & $\begin{array}{c}g_{S} \\
\left(\mathrm{~mol} \mathrm{~m}^{-2} \mathrm{~s}^{-1}\right) \\
\end{array}$ & $\begin{array}{c}C i \\
\left(\mu \mathrm{mol} \mathrm{mol}{ }^{-1}\right)\end{array}$ & $\begin{array}{c}E \\
\left(\mathrm{mmol} \mathrm{H}_{2} \mathrm{O} \mathrm{m}^{-2} \mathrm{~s}^{-1}\right)\end{array}$ \\
\hline Absence & $9.84 \mathrm{~b}$ & $0.33 \mathrm{a}$ & $305.50 \mathrm{a}$ & $10.09 \mathrm{a}$ \\
\hline Presence & $11.54 \mathrm{a}$ & $0.37 \mathrm{a}$ & $306.51 \mathrm{a}$ & $10.93 \mathrm{a}$ \\
\hline$\overline{\boldsymbol{X}}$ & 10.69 & 0.35 & 306.00 & 10.51 \\
\hline
\end{tabular}

(1) Means followed by the same small letter in the column among the different genotypes belong to the same Scott-Knott grouping and between presence and absence of IBA are not significantly different by the Tukey's test at 5\% probability level.

the present experiment, which may be attributed to the specific characteristics of each cultivar and the different propagation methods. Pires et al. (2011) reported $A$ values of 21.09 (P. morifolia); 16.15 (P. palmeri var. sublanceolata) and $12.36 \mu \mathrm{mol}$ $\mathrm{m}^{-2} \mathrm{~s}^{-1}$ (P. suberosa litoralis). The authors ascribed the differentiated behavior among the species to $\mathrm{CO}_{2}$ assimilation, as indicated by differences in the anatomical characteristics such as upper and lower epidermis thickness, palisade parenchyma, lacunar parenchyma, cuticle and mesophyll.

In this study, field seedlings of $P$. mucronata showed values of $10.69 \mu \mathrm{mol} \mathrm{CO}_{2} \mathrm{~m}^{-2} \mathrm{~s}^{-1}$ for $A$ and $0.35 \mathrm{~mol} \mathrm{~m}^{-2} \mathrm{~s}^{-1}$ for $g s$ (Table II). Freire et al. (2014) reported $2.56 \mu \mathrm{mol} \mathrm{CO} \mathrm{Cm}^{-2} \mathrm{~s}^{-1}$ for $A$ and $0.18 \mathrm{~mol} \mathrm{~m}^{-2} \mathrm{~s}^{-1}$ for $g s$ in P. edulis f. flavicarpa at the flowering stage. The photosynthetic variations can be influenced by a number of factors such as climatic conditions, as it was found in P. edulis Sims in three sites of the Colombian Andes. In this sense, although the photosynthetic capacity is adequate in two different sites, there may be specific limitations regarding low radiation and other climatic variations between night and day, including temperature, vapor pressure deficit, and relative humidity interfering with the recovery of water potential during the night and affecting the physiological performance (Martinez and Melgarejo 2015).

On the other hand, the limitation in photosynthesis and transpiration occurs mainly due to changes in $\mathrm{CO}_{2}$ diffusion from the atmosphere to the carboxylation site (Flexas et al. 2006, Warren et al. 2011). According to Taiz and Zeiger (2013), the reduction in $E$ may be associated with stomatal closure, which is a strategy used by the plant to support water status. Cavalcante et al. (2001), evaluating gas exchange in $P$. edulis f. flavicarpa, found means of 1.75 and $4.8 \mathrm{mmol} \mathrm{H}_{2} \mathrm{O} \mathrm{m}^{-2} \mathrm{~s}^{-1}$ for $E$ in the presence and absence of water stress, 
respectively. Carr (2013) studied the water relations of $P$. edulis and found that leaf production and expansion are sensitive to water deficit, reducing leaf number and delaying floral bud initiation, which will determine an uneven distribution of the fruit harvest during the year.

The species $P$. mucronata presents a transpiration far superior to $P$. edulis f. flavicarpa (Cavalcante et al. 2001), since it is being cultivated outside its natural occurrence area (restinga), which explains the plant is trying to maintain a balanced temperature, since the evaporation of water has the consequence of energy dissipation (heat), which avoids intense heating and thus, contributes to survival.

The clonal seedlings of GENs 3, 5, 6, 8 and 9 treated with IBA $\left(1000 \mathrm{mg} \mathrm{kg}^{-1}\right)$ had higher root dry mass (RDM) (Table III). Alexandre et al. (2014) reported that accumulation of RDM in cuttings of P. mucronata increased linearly until the maximum IBA (1000 mg kg ${ }^{-1}$ ) concentration, probably because of the high root vigor, performance and subsequent adaptation of these genotypes. Clonal seedlings of all GEN treated with IBA $\left(1000 \mathrm{mg} \mathrm{kg}^{-}\right.$ $\left.{ }^{1}\right)$ had a higher aerial part dry mass (SDM) (Table III). In this case, the action of auxin is confirmed by growth stimulated through cell division, whose importance is the faster development of the aerial part providing adequate conditions for flowering and fruit production. Fachinello et al. (2005) explained that the difference among genotypes is a function of endogenous auxin concentrations, and the amount supplied to each species or cultivar. Therefore, optimal concentrations of the plant regulator may differ completely among species, populations or clones, promoting or inhibiting root development. These fluctuations in rooting ability occur even among closely related individuals, suggesting the influence of endogenous determinism (Mankessi et al. 2009).

Morphological and physiological characteristics are important for analyzing the behavior of plants under adverse conditions. Some of these characteristics are destructive and some are not. The correlations between the non-destructive characteristics can help the understanding of the plant's growth without affecting the mother plant. The phenotypic correlation coefficients between the characteristics R and RRP were classified as very strong ( $\mathrm{rf}=0.9242^{* *}$ ), according to Carvalho et al. (2004) (Table IV). This information is essential to understand the responsiveness of each genotype to adventitious rooting, telling which genetic material is more vigorous, with greater precocity for clonal seedling production. Carvalho et al. (2004) also classified the correlation $g s$ vs. $E$ as strong (rf $\left.=0.8688^{* *}\right)$ and the correlations $E$ vs. RDM (rf $=$ $0.646^{* *}$ ), RRP vs. RDM ( $\mathrm{rf}=0.6709^{* *}$ ), SDM vs. $\mathrm{RDM}\left(\mathrm{rf}=0.6516^{* *}\right)$ and $A$ vs. $g s\left(\mathrm{rf}=0.6209^{* *}\right)$ as moderate (Table IV). These results allow us to infer, for example, that the greater the root vigor, the greater the root emergence porcentage. Another phenotypic correlation classified as strong is $g s$ vs. $E$ (Table IV), indicating that the higher the $g s$, the greater the $E$. Santos et al. (2016) studied the morphophysiology of $P$. cincinnata Mast under different conditions of propagation and spacings and found positive correlation between leaf area and transpiration (Pearson correlation $=0.6887$, significant at $1 \%$ probability by the $t$-test), meaning that the internal water status of the plant became less favorable for seed-derived plants, mainly because of the greater leaf area, with greater gas exchange between plants and atmosphere. The vapor loss to atmosphere can be maximized with greater stomatal conductance, inducing stomatal opening by reducing the relative humidity. Sánchez et al. (2013) found that the stomatal density in leaves of P. edulis is 106.53 stomata per square millimeter, leading to a negative correlation between stomatal opening and relative humidity; however, the propagation method had no effect on transpiration. 
TABLE III

Root dry mass (g) and shoot dry mass (g) of nine P. mucronata genotypes from adventitious rooting of cuttings treated and untreated indole-3-butyric acid (IBA).

\begin{tabular}{|c|c|c|c|c|}
\hline \multirow[b]{3}{*}{ Genotypes } & \multirow{2}{*}{$\begin{array}{c}\text { Root dry mass (g) } \\
\left.\text { IBA (1000 mg kg }{ }^{-1}\right)\end{array}$} & \multicolumn{3}{|c|}{ Shoot dry mass (g) } \\
\hline & & \multicolumn{3}{|c|}{ IBA (1000 mg kg $\left.{ }^{-1}\right)$} \\
\hline & Absence & Presence & Absence & Presence \\
\hline 1 & $36.28 \mathrm{Aa}^{(1)}$ & $33.45 \mathrm{Ba}$ & $49.11 \mathrm{Aa}^{(1)}$ & $64.20 \mathrm{Ba}$ \\
\hline 2 & $31.38 \mathrm{Aa}$ & $34.93 \mathrm{Ba}$ & $50.62 \mathrm{Aa}$ & $34.69 \mathrm{Ca}$ \\
\hline 3 & $40.74 \mathrm{Ab}$ & $60.13 \mathrm{Aa}$ & $44.04 \mathrm{Ab}$ & $70.79 \mathrm{Ba}$ \\
\hline 4 & $22.69 \mathrm{Ba}$ & $31.51 \mathrm{Ba}$ & $43.74 \mathrm{Aa}$ & $57.76 \mathrm{Ba}$ \\
\hline 5 & $38.84 \mathrm{Ab}$ & $57.25 \mathrm{Aa}$ & $54.88 \mathrm{Ab}$ & $75.45 \mathrm{Ba}$ \\
\hline 6 & $17.08 \mathrm{Bb}$ & $28.48 \mathrm{Ba}$ & $25.29 \mathrm{Ba}$ & $32.92 \mathrm{Ca}$ \\
\hline 7 & $23.51 \mathrm{Ba}$ & $23.98 \mathrm{Ba}$ & $34.16 \mathrm{Ba}$ & $31.25 \mathrm{Ca}$ \\
\hline 8 & $25.51 \mathrm{Bb}$ & $53.41 \mathrm{Aa}$ & $53.94 \mathrm{Ab}$ & $88.83 \mathrm{Aa}$ \\
\hline 9 & $23.59 \mathrm{Bb}$ & $50.21 \mathrm{Aa}$ & $57.00 \mathrm{Ab}$ & $86.55 \mathrm{Aa}$ \\
\hline
\end{tabular}

${ }^{(1)}$ Means followed by the same capital letter in the columns and small letter in the rows are not significantly different by the ScottKnott's grouping test and Tukey's mean test at 5\% probability level.

EXPERIMENT II: MOLECULAR DIVERSITY OF $P$. mucronata GENOTYPES.

Based on the criterion proposed by Singh (1981), the relative character contribution to the genetic diversity among the nine genotypes studied in the absence of IBA, in descending order of characteristics, is: RRP (38.75\%), R (20.27\%) and RDM (15.87\%) with $74.89 \%$ of the total distribution; and in the presence of IBA: $g s$ (23.19\%), RDM (20.91\%) and SDM (19.66\%) with $63.76 \%$ of the total distribution (Table V), which are therefore considered the most important characteristics in the present study.

In the absence of IBA, the first two canonical variables explained $89.35 \%$ of the total variation (69.21\% by the first canonical variable and $20.14 \%$ by the second canonical variable) (Figure 1a). In the presence of IBA, the first two canonical variables explained $91.82 \%$ of the total variation $(80.12 \%$ by the first canonical variable and $11.70 \%$ by the second canonical variable) (Figure 1b). Because the two canonical variables provided a satisfactory interpretation of the variability, more than $80 \%$ of the total variation among the genotypes (Cruz et al. 2012), in the presence and absence of IBA, the genetic diversity can be represented in a bidimensional scatter plot (Figure 1a, b).

The groups formed by graphic dispersion may not comprise in their totality the projection of the distances on the plane, however, it is up to the researcher to make sense of them (Sudré et al. 2005). The Tocher's optimization method separated the genotypes into three groups, with similar behavior within group and divergent behavior between groups, for both IBA-untreated cuttings (Figure 1a) and IBA-treated cuttings. This optimization technique groups individuals so that intra-group distances are always smaller than the intergroup distances (Cruz et al. 2012). Genotypes in the absence and presence of IBA were not clustered into the same groups. The largest group formed in the absence of IBA included GENs 1, 2, 6, 7, and 8 , while in the presence of IBA, it included GENs 1, 2, 4, 6, and 7. These GENs yielded low-rooting cuttings, below $50 \%$, even with IBA treatment (Table I). GENs 3, 5, and 9 were separated between the other two groups. In practical terms, considering the purposes of this study, for immediate grafting of $P$. edulis onto P. mucronata and maintenance 
TABLE IV

Phenotypic correlation coefficients between the characteristics rooting $(\mathrm{R}, \%)$; rate of root protrusion (RRP), mean root protrusion time (MRPT, days), shoot dry mass (SDM, g), root dry mass (RDM, g), net photosynthesis $\left(A, \mu \mathrm{mol} \mathrm{CO}_{2} \mathrm{~m}^{-2}\right.$ $\left.\mathrm{s}^{-1}\right)$, stomatal conductance $\left(g_{S}, \mathrm{~mol} \mathrm{~m}^{-2} \mathrm{~s}^{-1}\right)$, internal $\mathrm{CO}_{2}$ concentration $\left(C_{i}, \mu \mathrm{mol} \mathrm{m} \mathrm{m}^{-2}\right)$, and transpiration $\left(E, \mathrm{mmol} \mathrm{H}_{2} \mathrm{O}\right.$ $\left.\mathrm{m}^{-2} \mathrm{~s}^{-1}\right)$ for $P$. mucronata genotypes.

\begin{tabular}{|c|c|c|c|c|c|c|c|c|c|}
\hline CAR & $\mathbf{R}$ & RPR & MTRP & SDM & RDM & $A$ & $g_{S}$ & $C_{i}$ & $E$ \\
\hline $\mathbf{R}$ & - & $0.9242^{* *}$ & $-0.2167^{\mathrm{ns}}$ & $0.4928^{* *}$ & $0.646^{* *}$ & $0.2903^{*}$ & $0.2678^{*}$ & $-0.1267^{\text {ns }}$ & $0.2713^{* *}$ \\
\hline RPR & & - & $-0.4059^{* *}$ & $0.4705^{* *}$ & $0.6709^{* *}$ & $0.2434^{*}$ & $0.2689^{*}$ & $-0.025^{\mathrm{ns}}$ & $0.2603^{*}$ \\
\hline MTRP & & & - & $-0.3059^{* *}$ & $-0.3974^{* *}$ & $0.0923^{\mathrm{ns}}$ & $-0.0081^{\mathrm{ns}}$ & $-0.1004^{\mathrm{ns}}$ & $-0.0284^{\mathrm{ns}}$ \\
\hline SDM & & & & - & $0.6516^{* *}$ & $0.1969^{\mathrm{ns}}$ & $0.1595^{\mathrm{ns}}$ & $0.0002^{\mathrm{ns}}$ & $0.1487^{\text {ns }}$ \\
\hline RDM & & & & & - & $0.1549^{\mathrm{ns}}$ & $0.1512^{\mathrm{ns}}$ & $-0.0759^{\mathrm{ns}}$ & $0.041^{\mathrm{ns}}$ \\
\hline$A$ & & & & & & - & $0.6209^{* *}$ & $-0.0978^{\mathrm{ns}}$ & $0.562^{* *}$ \\
\hline$g_{S}$ & & & & & & & - & $0.5375^{* *}$ & $0.8688^{* *}$ \\
\hline$C_{i}$ & & & & & & & & - & $0.4894^{* *}$ \\
\hline$E$ & & & & & & & & & - \\
\hline
\end{tabular}

${ }^{(\mathrm{Ns})}$ Non significant and $(*, * *)$ Significant at $5 \%$ and $1 \%$ level of probability, by the $t$ test, respectively. Legend: CAR. characteristic.

TABLE V

Relative contribution of characteristics to diversity, according to the Singh (1981) criterion based on Mahalanobis' $\mathrm{D}^{2}$ statistics.

\begin{tabular}{|c|c|c|c|c|}
\hline \multirow[b]{3}{*}{ Variables } & \multicolumn{4}{|c|}{ IBA (1000 mg kg-1) } \\
\hline & \multicolumn{2}{|c|}{ Absence } & \multicolumn{2}{|c|}{ Presence } \\
\hline & S.j & Value (\%) & S.j & Value (\%) \\
\hline $\mathbf{R}(\%)$ & 405.593776 & 20.2778 & 261.333531 & 7.894 \\
\hline RPR & 775.115333 & 38.7522 & 503.489149 & 15.2087 \\
\hline MTRP (days) & 10.206293 & 0.5103 & 5.828051 & 0.176 \\
\hline SDM (g) & 109.32378 & 5.4657 & 651.059349 & 19.6663 \\
\hline RDM (g) & 317.571536 & 15.8771 & 692.390314 & 20.9147 \\
\hline$A\left(\mu \mathrm{mol} \mathrm{CO} \mathrm{m}^{-2} \mathrm{~s}^{-1}\right)$ & 116.360199 & 5.8175 & 1.916722 & 0.0579 \\
\hline$g_{S}\left(\mathrm{~mol} \mathrm{~m} \mathrm{~m}^{-2} \mathrm{~s}^{-1}\right)$ & 117.381024 & 5.8688 & 767.912682 & 23.196 \\
\hline$C_{i}\left(\mu \mathrm{mol} \mathrm{mol} \mathbf{l}^{1}\right)$ & 0.608646 & 0.0304 & 197.100653 & 5.9537 \\
\hline$E\left(\mathrm{mmol} \mathrm{H}_{2} \mathrm{O} \mathrm{m}^{-2} \mathrm{~s}^{-1}\right)$ & 148.022468 & 7.4004 & 229.506956 & 6.9326 \\
\hline
\end{tabular}

Legend: rooting (R, \%); rate of root protrusion (RRP), mean root protrusion time (MRPT, days), shoot dry mass (SDM, g), root dry mass (RDM, g), net photosynthesis $\left(A, \mu \mathrm{mol} \mathrm{CO} \mathrm{m}^{-2} \mathrm{~s}^{-1}\right)$, stomatal conductance $\left(g_{S}\right.$, mol m $\left.\mathrm{m}^{-2} \mathrm{~s}^{-1}\right)$, internal $\mathrm{CO}_{2}\left(C_{i}, \mu \mathrm{mol} \mathrm{m}^{-2} \mathrm{~s}^{-1}\right)$, and transpiration $\left(E, \mathrm{mmol} \mathrm{H}_{2} \mathrm{O} \mathrm{m}^{-2} \mathrm{~s}^{-1}\right)$.

of genetic diversity in rootstocks, we recommend GENs 3, 5, and 9.

Breeders can take advantage of the genetic diversity found among these genotypes to develop hybrid rootstocks from the crosses between the GENs of the largest group (1, 2, 4, 6, and 7) and the other two groups formed by GEN 3 and GENs 5,8 , and 9. These hybrids should be screened for vigor, mainly in relation to rooting, so to become economically viable with at least $70 \%$ of rooted cuttings as suggested by Hartmann et al. (2011).

The analysis of ISSR molecular markers showed that the nine GENs were clustered into three groups (I: 7, 9, 5, and 8; II: 1 and 6; III: 3, 4, and 2) (Figure 2). There was consistency between genotype groupings for morphological characteristics (Table I) and phenotypic (Figure 1) and molecular divergence (Figure 2). GENs 3 and 
(a)

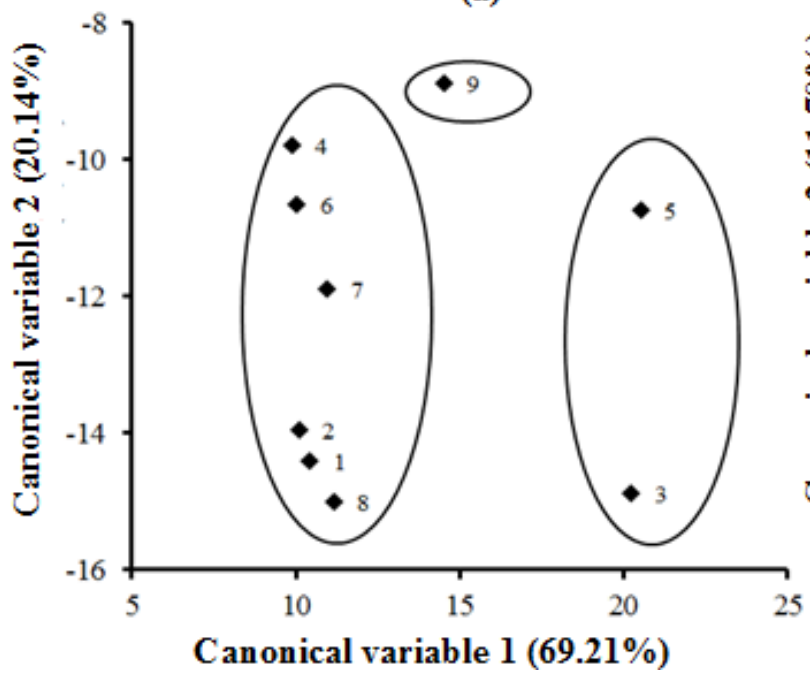

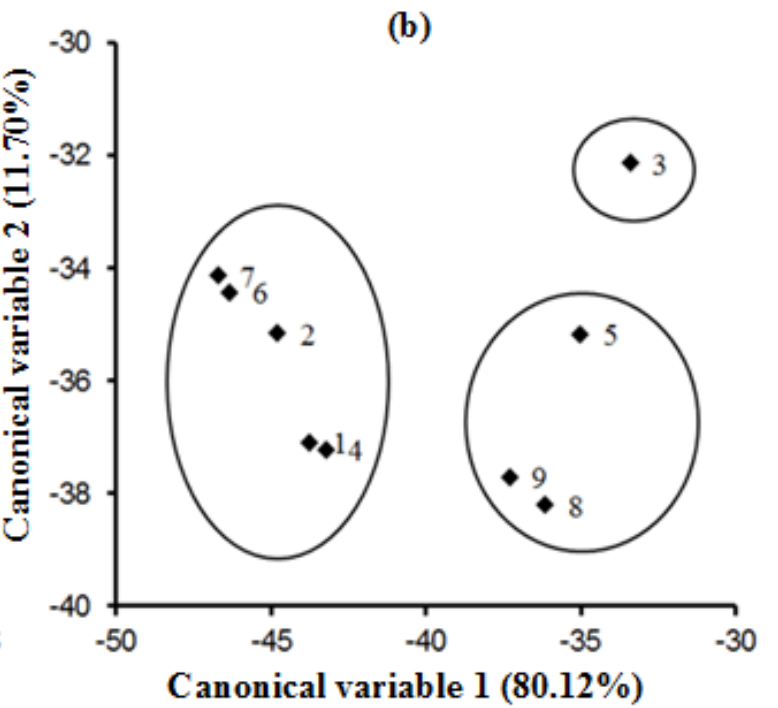

Figure 1 - Scatter plot of the first two canonical variables for morphological characteristics of production of $P$. mucronata clonal seedlings, in the absence (a) and presence (b) of IBA, grouped by the Tocher's method. Legend: rooting (\%); rate of root protrusion, mean root protrusion time (days), shoot dry mass $(\mathrm{g})$, root dry mass $(\mathrm{g})$, net photosynthesis $\left(\mu \mathrm{mol} \mathrm{CO}_{2} \mathrm{~m}^{-2} \mathrm{~s}^{-1}\right)$, stomatal conductance $\left(\mathrm{mol} \mathrm{m}^{-2} \mathrm{~s}^{-1}\right)$, internal $\mathrm{CO}_{2}$ concentration $\left(\mu \mathrm{mol} \mathrm{m} \mathrm{m}^{-2}\right)$, and transpiration $\left(\mathrm{mmol} \mathrm{H}_{2} \mathrm{O} \mathrm{m}^{-2} \mathrm{~s}^{-1}\right)$.

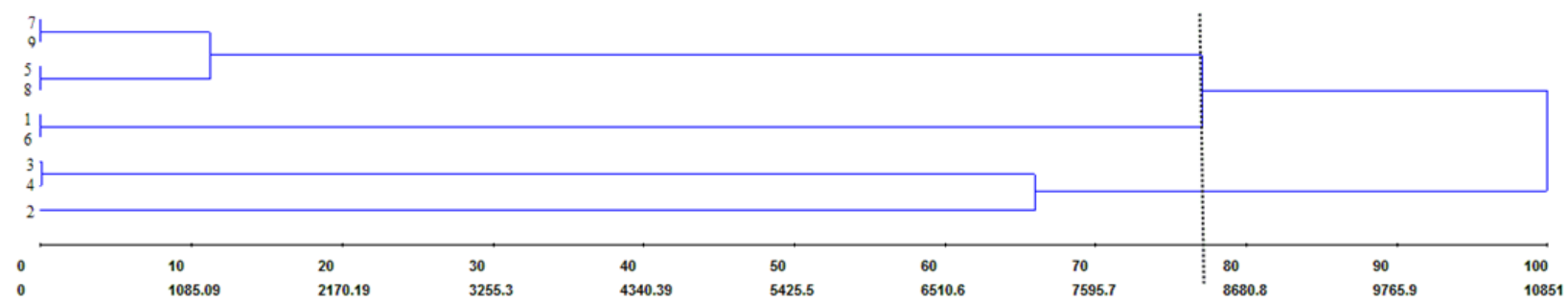

Figure 2 - UPGMA dendrogram of genetic dissimilarity among nine P. mucronata genotypes based on ISSR markers.

5 are considered as superior (mainly good rooting capacity) and genetically divergent, therefore, they may be good options for immediate use as rootstocks, or alternatively used in breeding programs to develop hybrid rootstocks. In the same way, GENs 3 and 9 can also be used.

The performance of these nine GENs for resistance to a fungal complex causing collar rot (Fusarium solani) (data not shown) is being analyzed. Finding resistant individuals in these groups allows, via cross-breeding, to produce individuals resistant to more than one type of fungus that causes this disease. These materials can be used as rootstocks for commercial passion fruit, considering that in recent studies the species P. mucronata was found to have high compatibility with the species $P$. edulis f. flavicarpa (Alexandre et al. 2013, Oliari et al. 2016). This allows in the near future the selection of individuals resistant to Fusarium solani and high rooting capacity using vegetative propagation by cuttings.

\section{CONCLUSIONS}

IBA exogenous induction of $P$. mucronata cuttings increased percentage and rate of rooting and reduced the mean time of rooting in eight days.

The rooting and growth responses varied among the genotypes, with GEN 5 being the most responsive in the absence of IBA and GENs 3, 8, and 9 the most responsive in the presence of IBA, providing intraspecific divergence. 
Genotypes derived from IBA treated cuttings showed higher net photosynthetic rate.

The IBA increases dry root and shoot mass in 55.55 and $44.44 \%$ of the genotypes, respectively.

\section{ACKNOWLEDGMENTS}

The first author thanks the Fundação de Amparo à Pesquisa e Inovação do Espírito Santo (FAPES) for granting the research grant.

\section{REFERENCES}

AHKAMI AH, MELZER M, GHAFFARI MR, POLLMANN S, JAVID MG, SHAHINNIA F, HAJIREZAEI MR AND DRUEGE U. 2013. Distribution of indole-3-acetic acid in Petunia hybrida shoot tip cuttings and relationship between auxin transport, carbohydrate metabolism and adventitious root formation. Planta 238: 499-517.

AIELLO AS AND GRAVES WR. 1998. Success varies when using subirrigation instead of mist to root softwood cuttings of woody taxa. J Environ Hort 16(1): 42-47.

ALBUQUERQUE JUNIOR CL, DANNER MA, KANIS LA, DESCHAMPS C, ZANETTI F AND FARIAS PM. 2013. Enraizamento de estacas semilenhosas de maracujazeiro amarelo (Passiflora actinia Hook). Semina: Ci Agrárias 34: 3663-3668.

ALEXANDRE RS, COSTA PR, CHAGAS K, MAYRINCK LG, DETONI JL AND SCHMILDT ER. 2014. Enraizamento adventício de estacas do maracujazeiro silvestre Passiflora mucronata Lam.: forma de veiculação e concentrações do ácido indol-3-butírico. Rev Ceres 61: 567-571.

ALEXANDRE RS, COSTA PR, CHAGAS K, MAYRINCK LG, GILES JAD AND SCHMILDT ER. 2016. Different propagules and auxin concentration on rooting of passionflower sandbank. Rev Ceres 63: 589-592.

ALEXANDRE RS, FERRARI WR, MONTEIRO JUNIOR KR, CHAGAS K, SCHIMILD ER AND GONTIJO I. 2013. Enraizamento de estacas de genótipos de Passiflora alata Curtis em resposta a ausência e presença de ácido indol-3-butírico (AIB). Rev Ciên Agrar 56: 287-291.

ALEXANDRE RS, LOPES JC, TIRADENTES AT, BRUCKNER CH AND OTONI WC. 2013. Metodologia de minienxertia em maracujazeiros. Rev Bras Frutic 35(1): 329-332.

ANDRADE JÚNIOR S, ALEXANDRE RS, SCHMILDT ER, PARTELLI FL, FERRÃO MAG AND MAURI AL. 2013. Comparison between grafting and cutting as vegetative propagation methods for conilon coffee plants. Acta Sci Agron 35: 461-469.
CARR MKV. 2013. The water relations and irrigation requirements of passion fruit (Passiflora edulis Sims): a review. Expl Agric 49: 585-596.

CARVALHO FIF, LORENCETTI C AND BENIN G. 2004. Estimativas e implicações da correlação no melhoramento vegetal. Pelotas: Editora e Gráfica Universitária - UFPel, $141 \mathrm{p}$.

CAVALCANTE VMT, MAIA LC, NOGUEIRA RJMC AND SANTOS VF. 2001. Respostas fisiológicas em mudas de maracujazeiro-amarelo (Passiflora edulis Sims. f. flavicarpa Deg.) inoculadas com fungos micorrizicos arbusculares e submetidos a estresse hídrico. Acta Bot Bras 15: 379-390.

CRUZ CD. 2016. Genes Software - extended and integrated with the R, Matlab and Selegen. Acta Sci Agron 38(4): 547-552.

CRUZ CD, REGAZZI AJ AND CARNEIRO PCS. 2012. Modelos biométricos aplicados ao melhoramento genético. Viçosa: UFV, 514 p.

DOYLE JJ AND DOYLE JL. 1990. Isolation of plant DNA from fresh tissue. Focus 12: 13-15.

FACHINELLO JC, HOFFMANN A, NACHTIGAL JC AND KERSTEN E. 2005. Propagação vegetativa por estaquia. In: Fachinello JC, Hoffmann A and Nachtigal JC (Eds), Propagação de plantas frutíferas, Brasília: Embrapa Informação Tecnológica, Brasília, BR, p. 57-221.

FLEXAS J, BOTA J, GALMÉS J, MEDRANO HAND RIBASCARBÓ M. 2006. Keeping a positive carbon balance under adverse conditions: responses of photosynthesis and respiration to water stress. Physiol Plant 127: 343-352.

FREIRE JLO, DIAS TJ, CAVALCANTE LF, FERNANDES PD AND LIMA NETO AJ. 2014. Rendimento quântico e trocas gasosas em maracujazeiro amarelo sob salinidade hídrica, biofertilização e cobertura morta. Rev Ciênc Agron 45: 82-91.

FREITAS JCO, VIANA AP, SANTOS EA, PAIVA CL, LIMA E SILVA FH, AMARAL JÚNIOR AT, SOUZA MM AND DIAS VM. 2015. Resistance to Fusarium solani and characterization of hybrids from the cross between P. mucronata and P. edulis. Euphytica (Wageningen) 1: 1546-1553.

GAMA VN, CUNHA JT, LIMA IM, BACARIN MA AND SILVA DM. 2013. Photosynthetic characteristics and quality of five passion fruit varieties under field conditions. Acta Physiol Plant 35: 941-948.

HARTMANN HT, KESTER DE, DAVIES JUNIOR DFT AND GENEVE RL. 2011. Plant propagation: principles and practices, $8^{\text {th }}$ ed., Boston: Prentice Hall, 915 p.

HUSEN A. 2008. Clonal propagation of Dalbergia sissoo Roxb. and associated metabolic changes during adventitious root primordium development. New Forest 36: 13-27.

ISUTSA DK. 2006. Performance of micropropagated and conventional passion fruit (Passiflora edulis Sims.) 
varieties in three contrasting agroecological zones. Egerton J Sci \& Technol 6: 87-102.

JUNQUEIRA NTV, ANSELMO RM, PINTO ACQ, RAMOS VHV, PEREIRA AV AND NASCIMENTO AC. 2003. Severidade da antracnose e perda de matéria fresca de frutos de dez procedências de maracujazeiro-doce (Passiflora alata Dryander) em dois ambientes de armazenamento. Rev Bras Frutic 25: 71-73.

JUNQUEIRA NTV, BRAGA MF, FALEIRO FG, PEIXOTO JR AND BERNACCI LC. 2005. Potencial de espécies silvestres de maracujazeiro como fonte de resistência a doenças. In: Faleiro FG, Junqueira NTV and Braga MF (Eds), Maracujá: germoplasma e melhoramento genético, Planaltina: Embrapa Cerrados, p. 81-106.

KLERK GJ, KEPPEL M, TERBRUGGE J AND MEEKES H. 1995. Timing of the phases in adventitious root formation in apple microcuttings. J Exp Bot 46: 965-972.

LI SW, SHI RF, LENG Y AND ZHOU Y. 2016. Transcriptomic analysis reveals the gene expression profile that specifically responds to IBA during adventitious rooting in mung bean seedlings. BMC Genomics 17(43): 1-23.

LI SW, XUE L, XU S, FENG H AND AN L. 2009. Mediators, genes and signaling in adventitious rooting. Bot Rev 75: 230-247.

MANKESSI F, SAYAA, BAPTISTE C, NOURISSIER S AND MONTEUUIS O. 2009. In vitro rooting of genetically related Eucalyptus urophylla x Eucalyptus grandis clones in relation to the time spent in culture. Trees 23: 931-940.

MAPA - MINISTÉRIO DA AGRICULTURA, PECUÁRIA E ABASTECIMENTO. 2007. Instrução Normativa SDA $N^{0}$ 17. Diário Oficial da União - Seção 1, no 99, 24 de maio de 2007. Métodos analíticos oficiais para análise de substratos para plantas e condicionadores de solo. Brasília.

MARTINEZ LVP AND MELGAREJO LM. 2015. Photosynthetic performance and leaf water potential of gulupa (Passiflora edulis Sims. passifloraceae) in the reproductive phase in three locations in the Colombian Andes. Acta Biol Colom 20: 183-194.

MELETTI LMM, SOARES-SCOTT MD, BERNACCI LC, ALVARES V AND AZEVEDO FILHO JÁ. 2011. Caracterização de Passiflora mucronata Lam.: nova alternativa de maracujá ornamental. Ornamental Horticulture 17(1): 87-95.

MOURI Y, MIYAHARA F, TSUTSUMI Y AND KONDO R. 2011. Effect of combination treatment with ethephon and indole-3-butyric acid on adventitious rooting of Pinus thunbergii cuttings. Plant Growth Regul 63: 271-278.

NEGISHI N, NAKAHAMA K, URATA N, KOJIMA M, SAKAKIBARA H AND KAWAOKA A. 2014. Hormone level analysis on adventitious root formation in Eucalyptus globulus. New Forest 45: 577-587.

OLIARI LS, GILES JAD, MAYRINCK LG, OLIVEIRA JPB, LOPES JC, OTONI WC, SCHMILDT ER, AOYAMA EM
AND ALEXANDRE RS. 2016. Mini-grafting of adult Passiflora edulis Sims. f. flavicarpa Deg. scions onto vegetatively propagated adult rootstocks of $P$. mucronata Lam. Aust J Crop Sci (Online) 10: 490-496.

PINTO PHD, PEIXOTO JR, JUNQUEIRA NTV, RESENDE RO, MATTOS JKA AND MELO B. 2008. Reação de genótipos de maracujazeiro-azedo ao vírus do endurecimento do fruto (Cowpea aphid-borne mosaic virus - CABMV). Biosci J 2: 19-26.

PIRES MV, ALMEIDA AF, FIGUEIREDO AL, GOMES FP AND SOUZA MM. 2011. Photosynthetic characteristics of ornamental passion flowers grown under different light intensities. Photosynthetica 49: 593-602.

PORFÍRIO S, SILVA MDRG, CABRITA MJ, AZADI P AND PEIXE A. 2016. Reviewing current knowledge on live (Olea europaea L.) adventitious root formation. Sci Horticult 198: 207-226.

PREISIGKE SC, MARTINI, FV, ROSSI AAB, SERAFIM ME, BARELLI AA, LUZ PB, ARAÚJO KL AND NEVES LG. 2015. Genetic variability of Passiflora spp. against colar rot disease. Aust J Crop Sci 9(1): 69-74.

SABIÃO RR, SILVAACC, MARTINS ABG AND CARDOSO ER. 2011. Enraizamento de estacas de Passiflora nitida submetidas a diferentes concentrações de ácido indolbutírico (AIB). Rev Bras Frutic, Volume Especial, p. 654-657.

SÁNCHEZ C, FISCHER G AND SANJUANELO DW. 2013. Stomatal behavior in fruits and leaves of the purple passion fruit (Passiflora edulis Sims.) and fruits and cladodes of the yellow pitaya [Hylocereus megalanthus (K. Schum. ex Vaupel) Ralf Bauer]. Agron Colomb 31: 38-47.

SANTOS JL, MATSUMOTO SN, OLIVEIRA PN, OLIVEIRA LS AND SILVA RA. 2016. Morphophysiological analysis of passion fruit plants from different propagation methods and planting spacing. R Caatinga 29: 305-312.

SECUNDINO W, ALEXANDRE RS, SCHMILDT ER, SCHMILDT O, MAGEVSKI GC AND MARTINS JPR. 2014. Rhizogenic behavior of black pepper cultivars to índole-3-butyric acid. Acta Sci Agron 36: 355-364.

SINGH D. 1981. The relative importance of characters affecting genetc divergence. Indian J Genet $\mathrm{P} 1 \mathrm{Br} 41$ : 237 245.

SOUSA CM, SANTOS MP AND CARVALHO BM. 2014. Enraizamento de estacas de maracujazeiro-doce (Passiflora alata Curtis). Científica 42: 68-73.

SOUZA ER, LENK FL, ONO EO AND RODRIGUES JD. 2015. Conteúdo de carboidratos em estacas de videira do porta-enxerto cv. IAC 572. Appl Res \& Agrotec 8: 7-15.

SUDRÉ CP, RODRIGUES R, RIVA EM, KARASAWA M AND AMARAL JÚNIOR AT. 2005. Divergência genética entre acessos de pimenta e pimentão utilizando técnicas multivariadas. Hort Bras 23(1): 22-27. 
TAIZ L AND ZEIGER E. 2013. Fisiologia Vegetal, 5ª ed., Porto Alegre: Artmed, $954 \mathrm{p}$.

VAZ CF, PEIXOTO JR, JUNQUEIRA NTV, BRAGA MF, SANTOS EC, FONSECA KG AND JUNQUEIRA KP. 2009. Enraizamento de espécies silvestres de maracujazeiro utilizando cinco doses de ácido indolilbutírico. Rev Bras Frutic 31: 816-822.

VASCONCELLOS MA, SILVA AC, SILVA AC AND REIS FO. 2005. Ecofisiologia do maracujazeiro e implicações na exploração diversificada. In: Faleiro FG, Junqueira NTV and Braga MF (Eds), Maracujá: germoplasma e melhoramento genético. Planaltina, DF: Embrapa Cerrados, p. 295-313.

VERSTRAETEN I, SCHOTTE S AND GEELEN D. 2014. Hypocotyl adventitious root organogenesis differs from lateral root development. Front Plant Sci 5: 1-13.
VILLACORTA-MARTÍN C, SÁNCHEZ-GARCÍA AB, VILLANOVA J, CANO A, VAN RM, HAAN J, ACOSTA M, PASSARINHO P AND PÉREZ-PÉREZ JM. 2015. Gene expression profiling during adventitious root formation in carnation stem cuttings. BMC Genomics 16: $2-18$.

WARREN CR, ARANDA I AND CANO FJ. 2011. Responses to water stress of gas exchange and metabolites in eucalyptus and Acacia spp. Plant Cell Environ 34: 16091629.

WENDLING I, BROOKS PR AND TRUEMAN SJ. 2015. Topophysis in Corymbia torelliana x C. citriodora seedlings: adventitious rooting capacity, stem anatomy, and auxin and abscisic acid concentrations. New Forest 46: $107-120$. 